\title{
$500 \mathrm{ml}$ of blood loss does not decrease
} non-invasive tissue oxygen saturation $\left(\mathrm{StO}_{2}\right)$ as measured by near infrared spectroscopy - A hypothesis generating pilot study in healthy adult women

\author{
Victor Jeger', Stephan M Jakob², Stefano Fontana³, Martin Wolf4, Heinz Zimmermann ${ }^{1}$ and \\ Aristomenis K Exadaktylos*1
}

\begin{abstract}
Background: The goal when resuscitating trauma patients is to achieve adequate tissue perfusion. One parameter of tissue perfusion is tissue oxygen saturation $\left(\mathrm{StO}_{2}\right)$, as measured by near infrared spectroscopy. Using a commercially available device, we investigated whether clinically relevant blood loss of $500 \mathrm{ml}$ in healthy volunteers can be detected by changes in $\mathrm{StO}_{2}$ after a standardized ischemic event.

Methods: We performed occlusion of the brachial artery for 3 minutes in 20 healthy female blood donors before and after blood donation. $\mathrm{StO}_{2}$ and total oxygenated tissue hemoglobin $\left(\mathrm{O}_{2} \mathrm{Hb}\right)$ were measured continuously at the thenar eminence. 10 healthy volunteers were assessed in the same way, to examine whether repeated vascular occlusion without blood donation exhibits time dependent effects.

Results: Blood donation caused a substantial decrease in systolic blood pressure, but did not affect resting $\mathrm{StO}_{2}$ and $\mathrm{O}_{2} \mathrm{Hb}$ values. No changes were measured in the blood donor group in the reaction to the vascular occlusion test, but in the control group there was an increase in the $\mathrm{O}_{2} \mathrm{Hb}$ rate of recovery during the reperfusion phase.

Conclusion: $\mathrm{StO}_{2}$ measured at the thenar eminence seems to be insensitive to blood loss of $500 \mathrm{ml}$ in this setting. Probably blood loss greater than this might lead to detectable changes guiding the treating physician. The exact cut off for detectable changes and the time effect on repeated vascular occlusion tests should be explored further. Until now no such data exist.
\end{abstract}

\section{Introduction}

The goal of resuscitation is to achieve adequate tissue perfusion. The patient's history, ongoing bleeding and clinical signs of hypovolemia are the first trigger for volume substitution. Tissue perfusion is conventionally monitored using arterial base deficit and serum lactate, but these laboratory parameters are not always immediately available at the point-of-care. Additionally, relevant

*Correspondence: exadaktylos@exadaktylos.ch

${ }^{1}$ Department of Emergency Medicine, University and University Hospital of Berne (Inselspital), Berne, Switzerland

Full list of author information is available at the end of the article blood loss may not be detected by conventional hemodynamic monitoring [1].

Therefore, in the trauma setting, there is growing interest in non-invasive techniques measuring tissue perfusion. Near infrared spectroscopy (NIRS) has become a widely used method for tissue hemoglobin oxygen saturation $\left(\mathrm{StO}_{2}\right)$ measurement in muscle and has been validated in animals [2-4] and in humans [5-11].

NIRS uses light with a wavelength of 650-950 nm and easily crosses biological tissues. Near infrared light is mainly absorbed by hemoglobin and only monitors vessels with a diameter $<1 \mathrm{~mm}$, because the blood levels in

( 2010 Jeger et al; licensee BioMed Central Ltd. This is an Open Access article distributed under the terms of the Creative Commons B. Wed Central Attribution License (http://creativecommons.org/licenses/by/2.0), which permits unrestricted use, distribution, and reproduction in any medium, provided the original work is properly cited. 
larger vessels are too high to reflect enough light [12]. In this setting, NIRS measurements primarily indicate the venous oxyhemoglobin concentration, as only $20 \%$ of blood volume is arterial and the NIRS device does not differentiate between systole and diastole [13].

NIRS can be used to observe the microcirculatory reactivity of peripheral tissue after a standardized ischemic event. It has been shown that $\mathrm{StO}_{2}$ recovery after transient occlusion of the brachial artery differs in hemodynamically unstable trauma patients in comparison to healthy volunteers [14]. The $\mathrm{StO}_{2}$ response after a vascular occlusion test is an example of functional hemodynamic monitoring, in which the response of the specific system to a pre-determined stress is the monitored variable. After induction of an artificial ischemic stress, local metabolic demand and reperfusion reserve can be assessed from the changes in parameters [14].

The aim of this study was to investigate the impact of a controlled and clinically relevant blood loss $(500 \mathrm{ml})$ on resting $\mathrm{StO}_{2}$ values, as well as microcirculatory reactivity triggered by a vascular occlusion test in healthy blood donors. $500 \mathrm{ml}$ of blood donation correspond to a loss of $10 \%$ of the whole blood volume. $10 \%$ of blood loss is considered to be the cut off for clinical relevant blood loss according to the current literature and may become relevant if pre- existing morbidity exists. For example, postpartum hemorrhage, defined as blood loss more than 500 $\mathrm{ml}$ after a vaginal delivery, is a major cause of maternal morbidity and mortality [15]. Other authors have been able to detect $500 \mathrm{ml}$ of blood loss with NIRS in various settings $[16,17]$.

We have decided to investigate the $500 \mathrm{ml}$ blood loss because of the controlled and safe study setting and because higher blood volume losses are anyway related with detectable changes in physiological parameters (e.g. blood pressure, pulse rate). For the clinician, "borderline" patients without obvious signs of blood loss present the greater challenge.

We hypothesized that NIRS after a vascular occlusion test would be able to detect this amount of blood loss, because of the industries promise of "earliest" detection of volume depletion.

\section{Methods}

\section{Volunteers}

We investigated 20 healthy female blood donors and 10 healthy female medical students as control subjects. The study was restricted to women, as they have lower body mass index (BMI) than men and are therefore more prone to show slight symptoms of hypovolemia after blood donation.

Blood donors had a median age of $30.5 \mathrm{y}$ (range 19 - 62). Their BMI was $21 \mathrm{~kg} / \mathrm{m}^{2}$ median (range 18 - 23.5). The median blood volume is estimated as $70 \mathrm{ml} / \mathrm{kg}$ body weight or $4060 \mathrm{ml}$ (range 3500 - 4550). The median capillary hemoglobin was $139 \mathrm{~g} / \mathrm{l}$ (range 127 - 157). This was measured once immediately after arrival at the blood donation service.

In the control group, the median age was $23 \mathrm{y}$ (range 22 - 25). The median BMI was $21 \mathrm{~kg} / \mathrm{m}^{2}$ (range 19 - 23). The median blood volume was $4165 \mathrm{ml}$ (range 3500 - 4480).

\section{Protocol}

Blood donors and control subjects were in a zero degree supine position during the whole test. In both groups, there was a resting period of 5 minutes before applying the probe and performing the vascular occlusion test measurement. We measured blood pressure manually before every vascular occlusion test, using the same sphygmomanometer cuff as when occluding the artery. Blood donation started after a recovery period of $5 \mathrm{~min}$ utes. The second vascular occlusion test in the blood donor group started immediately after the end of blood donation.

In the control group, measurements were performed in exactly the same way as in the blood donor group. In order to detect a possible time effect from the vascular occlusion tests, a 19-minute rest period was maintained between the two vascular occlusion tests of the control group. (Fig. 1) These 19 minutes are a median (range 14 22 minutes) measured in the blood donor group between the end of the first and the start of the second vascular occlusion test. This period included the recovery from the first vascular occlusion, the preparation for phlebotomy and the actual blood donation, which lasted 11 minutes (range 9 - 13).

As this was an observational study aimed at controlling the quality of a freely available device, and because no additional data were collected from the volunteers, no formal ethical approval was necessary, according to our local ethical committee. Additionally, the vascular occlusion using a cuff pressure of $50 \mathrm{mmHg}$ above systolic blood pressure, correlates to cuff pressures reached in non invasive (Riva Rocci) blood pressure measurement. Because no data on ethical considerations related to such kind of setting have been available, AKE and VJ have acted as volunteers. The discomfort has been within the usual limits of blood pressure measurement and was later very well tolerated by the volunteers and did not cause any discomfort.

\section{Measurements}

We measured $\mathrm{StO}_{2}$ at the thenar eminence (opposite to the blood donating arm) with a commercially available tissue spectrometer (InSpectra ${ }^{\circ}$ Model 650, Hutchinson Technology, Hutchinson, Minn. US), which is promoted as being able to detect blood loss in an emergency setting 


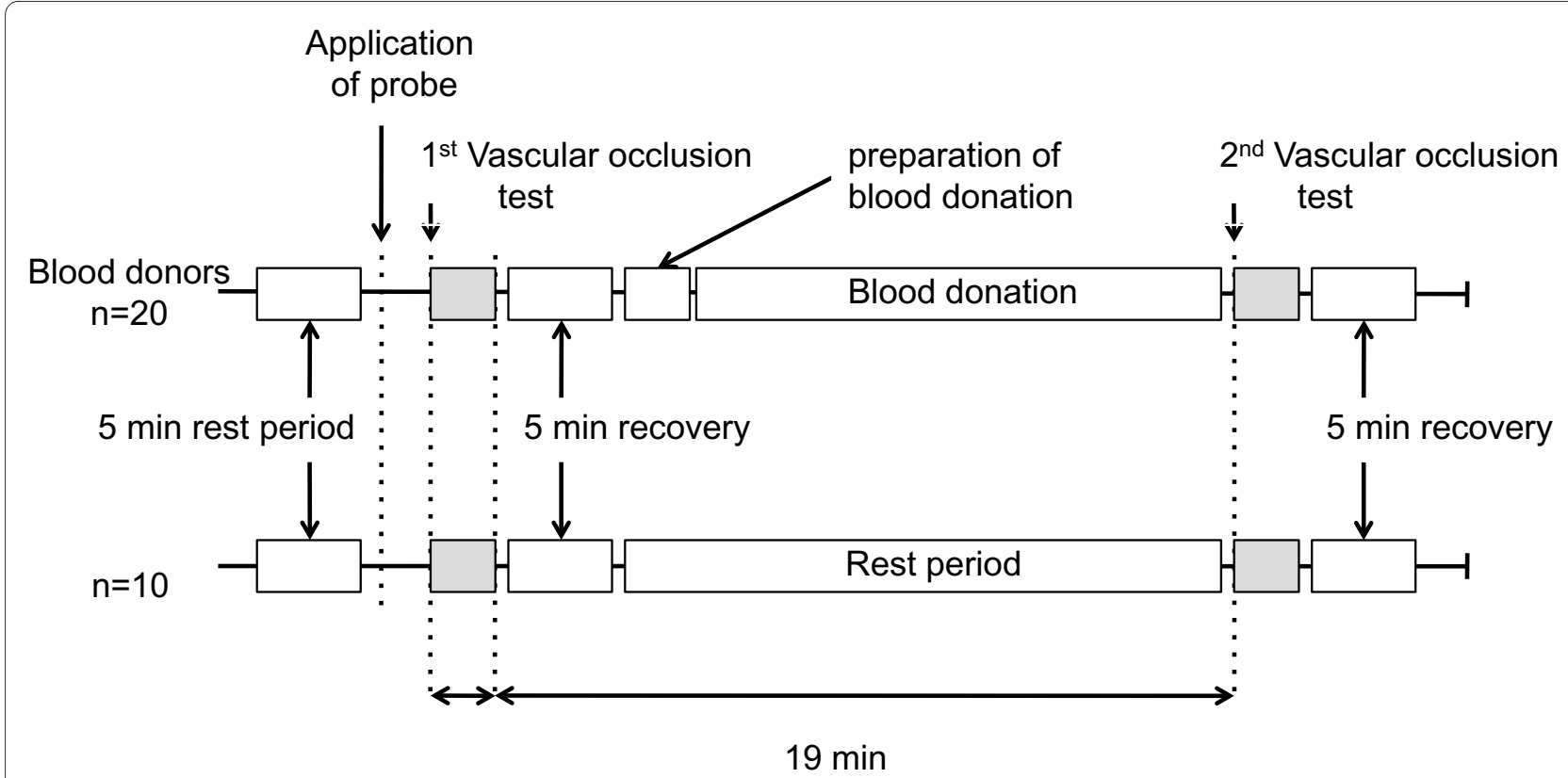

Figure 1 Time axis showing course of events for both groups

[18]. The method has been previously validated [19]. The probe spacing was $15 \mathrm{~mm}$.

The device measures and records $\mathrm{StO}_{2}$ and tissue hemoglobin index (THI) every two seconds. THI is a quantitative estimation of tissue hemoglobin concentration [20]. From these values, oxygenated hemoglobin $\left(\mathrm{O}_{2} \mathrm{Hb}\right)$ was obtained by multiplying $\mathrm{StO}_{2}$ and $\mathrm{THI}$, because $\mathrm{StO}_{2}=\frac{\mathrm{O}_{2} \mathrm{Hb}}{\mathrm{O}_{2} \mathrm{Hb}+\mathrm{HHb}}[19]$. Accordingly, the amount of deoxygenated hemoglobin $(\mathrm{HHb})$ equals the residual hemoglobin: $\mathrm{THI}-\mathrm{O}_{2} \mathrm{Hb}=\mathrm{HHb}$. We defined baseline variables before starting a vascular occlusion test as the median over 2 minutes for $\mathrm{StO}_{2}, \mathrm{O}_{2} \mathrm{Hb}$, and $\mathrm{HHb}$.

A vascular occlusion test was performed by inflating the sphygmomanometer cuff for 3 minutes with a pressure of $50 \mathrm{mmHg}$ over systolic BP as described in detail by Creteur et al. [12]. The rate of decrease was calculated from the linear part of the decrease (first 25\%) after cuff inflation [14]. The rate of recovery of $\mathrm{StO}_{2}$ and $\mathrm{O}_{2} \mathrm{Hb}$ was defined over a mean of 14 seconds (8 data points) following the nadir $\mathrm{StO}_{2}$ and $\mathrm{O}_{2} \mathrm{Hb}$ value at the end of ischemia. Delta $\mathrm{StO}_{2}$ and delta $\mathrm{O}_{2} \mathrm{Hb}$ are defined as the difference between the maximal value after reperfusion and the baseline [12]. (Fig. 2, Fig. 3)

\section{Data processing}

Prism 5 (GraphPad Software, Inc., San Diego, CA, USA) was used to calculate the statistics. Non-parametric tests were used (Wilcoxon rank sum test for within-group differences, Mann-Whitney U-test for between-group differences). Data is presented as medians and interquartile ranges. P-values have been interpreted in an exploratory fashion.

\section{Results}

There was a markedly decrease in systolic blood pressure in both groups before and after blood donation. Systolic

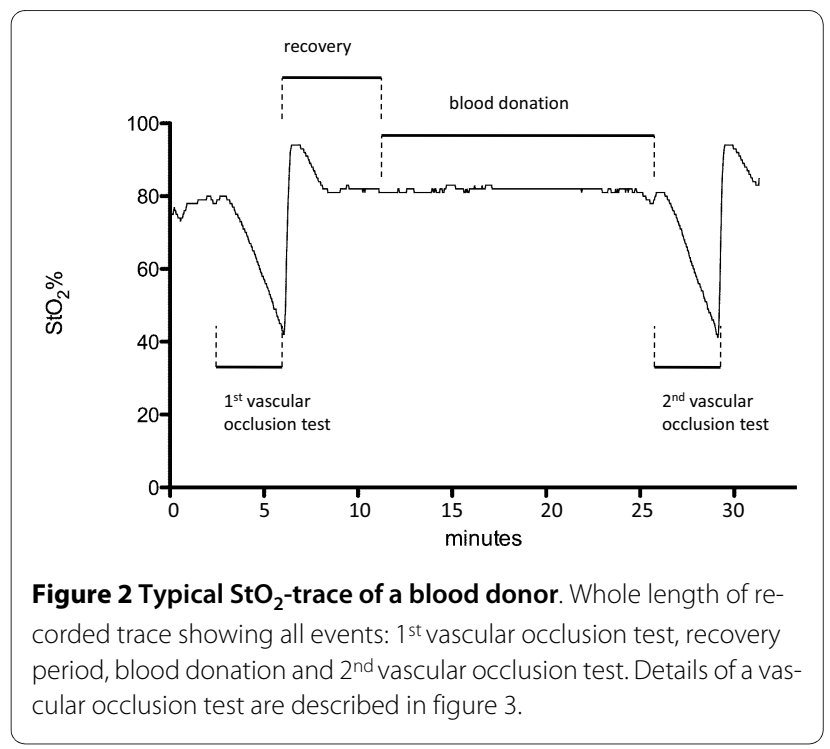




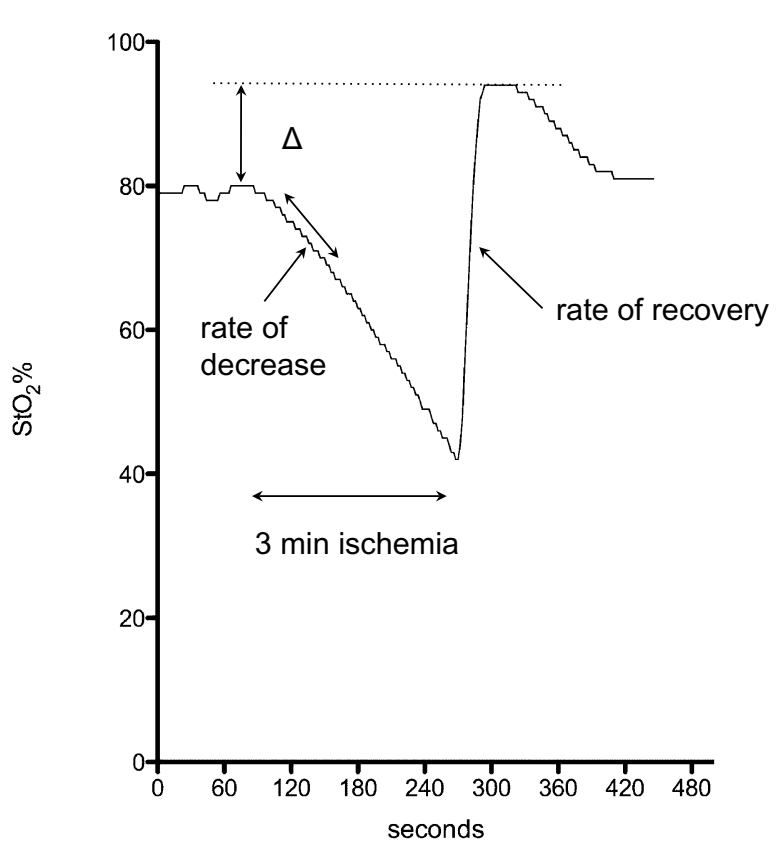

Figure 3 Focus on the reaction of a $\mathrm{StO}_{2}$-trace after a vascular occlusion test. $\Delta$ : delta, difference between $\mathrm{StO}_{2}$ max and $\mathrm{StO}_{2}$ baseline; rate of decrease (first 25\%); rate of recovery.

blood pressure decreased from $118 \mathrm{mmHg}$ median (interquartile range: 118 - 123) to $110 \mathrm{mmHg}(106-115)$ ( $\mathrm{p}<$ $0.001)$ in the donor group and from $112 \mathrm{mmHg}(103-$ $118)$ to $106 \mathrm{mmHg}(100-111)(\mathrm{p}=0.02)$ in the control group. Systolic blood pressure decreased markedly more in the donor group than in the control group $(\mathrm{p}=0.02)$. (Fig. 4)

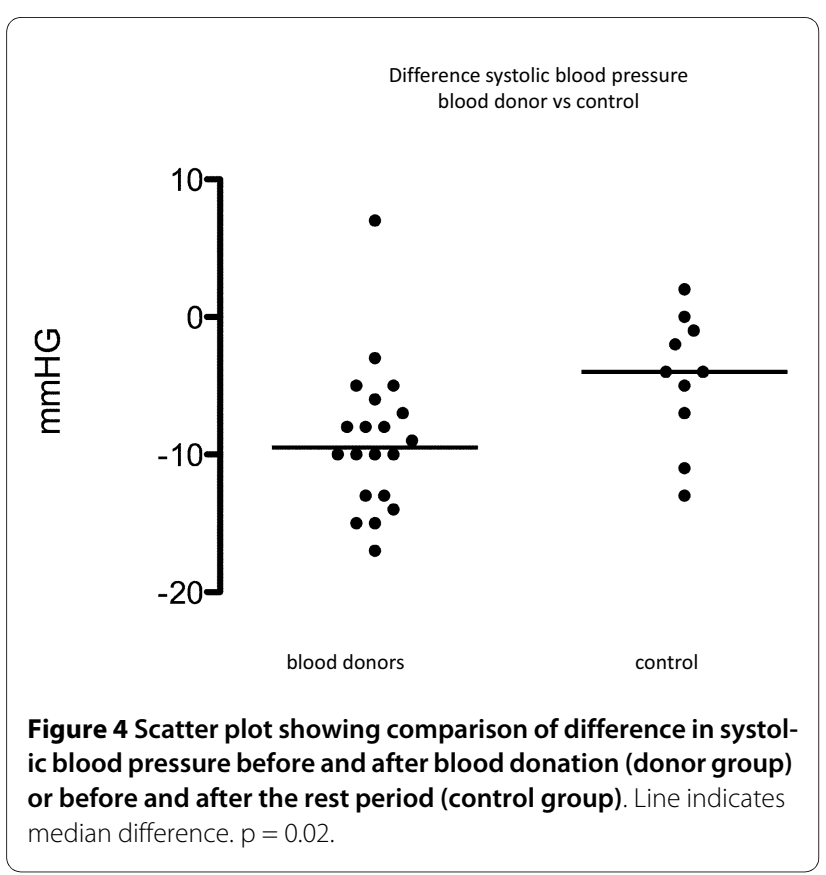

For variables measured with NIRS, the differences from the first to the second vascular occlusion test did not differ between the two groups. The only exception was the differences in $\mathrm{O}_{2} \mathrm{Hb} 2$ min median, which was slightly larger in the control group -0.4 $(-1.0--0.3)$ than in the blood donor group $-0.1(-0.4-0.3)(\mathrm{p}=0.03)$. Therefore the two groups are considered to be similar and comparable.

$\mathrm{StO}_{2}$ and $\mathrm{O}_{2} \mathrm{Hb} 2$ min median did not change substantially in the blood donor group before and after blood donation, but decreased in the control group after the rest period: $\mathrm{StO}_{2} 2$ min median decreased from $82.0 \%$ (79.5 - 85.0) to $80.5 \%(76.8-83.8)(\mathrm{p}=0.02), \mathrm{O}_{2} \mathrm{Hb} 2 \mathrm{~min}$ median decreased from $10.9(9.6$ - 12.4) to 10.2 (9.4 11.8) $(\mathrm{p}=0.03)$. HHb 2 min median did not change in the blood donor group, but increased in the control group markedly from $2.35(2.08-2.56)$ to $2.45(2.20-2.92)(\mathrm{p}=$ 0.01) (Table 1).

Variables measured during the vascular occlusion test did not change in the blood donor group: The rate of decrease, rate of recovery and delta for $\mathrm{StO}_{2}$ and $\mathrm{O}_{2} \mathrm{Hb}$ did not show any substantial difference before and after blood donation. In the control group, $\mathrm{StO}_{2}$ variables did not change markedly - in contrast to the $\mathrm{O}_{2} \mathrm{Hb}$ values. $\mathrm{O}_{2} \mathrm{Hb}$ rate of decrease was less steep after the rest period (before: -0.039 (-0.051 - -0.026); after: -0.031 (-0.046 - $0.020) ; \mathrm{p}<0.01$ ), whereas $\mathrm{O}_{2} \mathrm{Hb}$ rate of recovery (before: 0.49 (0.39 - 0.63); after: $0.54(0.39-0.69) ; \mathrm{p}=0.05)$ and $\mathrm{O}_{2} \mathrm{Hb}$ delta (before: 3.88 (2.43 - 4.20); after: 4.0 (3.32 5.72); $\mathrm{p}=0.01$ ) increased after the rest period (Table 2).

\section{Discussion}

The principal finding of this study is, that although systolic blood pressure decreased substantially, blood loss had no effect on superficial thenar $\mathrm{StO}_{2}$ before and after blood donation measured by NIRS. However other experimental NIRS devices have been successfully used to monitor blood loss after blood donation. Torella et al. showed that even $2 \%$ blood volume loss reduced peripheral hemoglobin oxygen saturation $\left(\mathrm{PsO}_{2}\right.$, calf $)$ significantly [16]. Soller et al. simulated hypovolemia using progressive lower body negative pressure and showed that hypovolemia corresponding to $400-500 \mathrm{ml}$ of blood loss resulted in a decrease in forearm muscle oxygen saturation [17]. The same group could also show, in the same setting, that deep muscle oxygen saturation is more sensitive in detecting hypovolemia (experimental NIRS device) than superficial thenar $\mathrm{StO}_{2}$ (Hutchinson) [21] Soller et al. discussed, that the location of the NIRS sensor as well as the tissue depth might be responsible for variations in results, although the technique used by the two devices is in principle the same. We did use exactly 
Table 1: NIRS variables and systolic blood pressure before each vascular occlusion test.

\begin{tabular}{|c|c|c|c|c|c|}
\hline \multirow[t]{2}{*}{ Blood donors } & \multicolumn{2}{|c|}{ Before blood donation } & \multicolumn{2}{|c|}{ After blood donation } & \multirow[b]{2}{*}{$\begin{array}{l}\text { two-tailed } p \text { - } \\
\text { value }\end{array}$} \\
\hline & median & IQR & median & IQR & \\
\hline $\mathrm{StO}_{2}$ & 79.0 & $74.5-83.5$ & 78.5 & $75.0-83.0$ & 0.34 \\
\hline $\mathrm{O}_{2} \mathrm{Hb}$ & 10.7 & $9.3-11.9$ & 10.8 & $8.9-11.7$ & 0.43 \\
\hline deoxy $\mathrm{Hb}$ & 2.62 & $2.39-3.24$ & 2.70 & $2.34-4.39$ & 0.30 \\
\hline SBP & 118 & $118-123$ & 110 & $106-115$ & $<0.001^{*}$ \\
\hline \multirow[t]{2}{*}{ Control } & \multicolumn{2}{|c|}{ Before rest period } & \multicolumn{2}{|c|}{ After rest period (19 minutes) } & \\
\hline & median & IQR & median & IQR & $\begin{array}{l}\text { two-tailed } \mathbf{p -} \\
\text { value }\end{array}$ \\
\hline $\mathrm{StO}_{2}$ & 82.0 & $79.5-85.0$ & 80.5 & $76.8-83.8$ & $<0.05^{*}$ \\
\hline $\mathrm{O}_{2} \mathrm{Hb}$ & 10.9 & $9.6-12.4$ & 10.2 & $9.4-11.8$ & $<0.05^{*}$ \\
\hline deoxy $\mathrm{Hb}$ & 2.35 & $2.08-2.56$ & 2.45 & $2.20-2.92$ & $<0.01^{*}$ \\
\hline SBP & 112 & $103-118$ & 106 & $100-111$ & $<0.05^{*}$ \\
\hline
\end{tabular}

IQR: interquartile range, ${ }^{*}: p<0.05$

Table 2: NIRS variables during the vascular occlusion tests.

\begin{tabular}{|c|c|c|c|c|c|}
\hline \multirow[t]{2}{*}{ Blood donors } & \multicolumn{2}{|c|}{ Before blood donation } & \multicolumn{2}{|c|}{ After blood donation } & \multirow[b]{2}{*}{$\begin{array}{c}\text { two-tailed } \\
\text { p-value }\end{array}$} \\
\hline & median & IQR & median & IQR & \\
\hline $\mathrm{StO}_{2}$ rate of decrease $(\% / \mathrm{sec})$ & -0.19 & $-0.21--0.16$ & -0.19 & $-0.23--0.15$ & 0.78 \\
\hline $\mathrm{StO}_{2}$ rate of recovery $(\% / \mathrm{sec})$ & 3.04 & $2.57-3.45$ & 3.29 & $2.79-3.48$ & 0.25 \\
\hline $\mathrm{StO}_{2}$ delta $(\%)$ & 14.0 & $12.0-15.8$ & 13.5 & $12.0-18.0$ & 0.36 \\
\hline $\mathrm{O}_{2} \mathrm{Hb}$ rate of decrease $(/ \mathrm{sec})$ & -0.033 & $-0.043--0.026$ & -0.027 & $-0.055--0.021$ & 0.98 \\
\hline $\mathrm{O}_{2} \mathrm{Hb}$ rate of recovery $(/ \mathrm{sec})$ & 0.59 & $0.50-0.72$ & 0.63 & $0.48-0.74$ & 0.59 \\
\hline $\mathrm{O}_{2} \mathrm{Hb}$ delta & 4.33 & $3.47-4.97$ & 4.76 & $4.24-5.42$ & 0.06 \\
\hline \multirow[t]{2}{*}{ Control } & \multicolumn{2}{|c|}{ Before rest period } & \multicolumn{2}{|c|}{ After rest period (19 minutes) } & \\
\hline & median & IQR & median & IQR & $\begin{array}{c}\text { two-tailed } \\
\text { p-value }\end{array}$ \\
\hline $\mathrm{StO}_{2}$ rate of decrease $(\% / \mathrm{sec})$ & -0.17 & $-0.19--0.15$ & -0.15 & $-0.20--0.12$ & 0.43 \\
\hline $\mathrm{StO}_{2}$ rate of recovery $(\% / \mathrm{sec})$ & 2.64 & $2.00-2.88$ & 2.43 & $2.00-3.47$ & 0.29 \\
\hline $\mathrm{StO}_{2}$ delta $(\%)$ & 12.5 & $11.3-13.3$ & 13.5 & $11.5-15.25$ & 0.10 \\
\hline $\mathrm{O}_{2} \mathrm{Hb}$ rate of decrease $(/ \mathrm{sec})$ & -0.039 & $-0.051--0.026$ & -0.031 & $-0.046--0.020$ & $<0.01^{*}$ \\
\hline $\mathrm{O}_{2} \mathrm{Hb}$ rate of recovery $(/ \mathrm{sec})$ & 0.49 & $0.39-0.63$ & 0.54 & $0.39-0.69$ & $<0.05^{*}$ \\
\hline $\mathrm{O}_{2} \mathrm{Hb}$ delta & 3.88 & $2.43-4.20$ & 4.00 & $3.32-5.72$ & $<0.01^{*}$ \\
\hline
\end{tabular}

IQR: interquartile range, ${ }^{*}: p<0.05$ 
the same superficial thenar $\mathrm{StO}_{2}$ probe from Hutchinson as Soller in her study, which may explain why we did not detect any changes in NIRS parameters following blood loss.

A second finding of this study is that there might be an intrinsic effect of repeated vascular occlusion tests on $\mathrm{O}_{2} \mathrm{Hb}$. This hypothesis is based on the increase in delta $\mathrm{O}_{2} \mathrm{Hb}$ and $\mathrm{O}_{2} \mathrm{Hb}$ rate of recovery and a decrease in oxygen consumption $\left(\mathrm{O}_{2} \mathrm{Hb}\right.$ rate of decrease), which was measured in the control group but not in the blood donor group. This could be explained if there is a time effect of repeated vascular occlusion tests, designated as ischemic preconditioning [22]. This improves the ischemic tolerance of various tissues, including skeletal muscle, after one or more brief periods of ischemia, each followed by a short reperfusion phase. The underlying mechanisms are still not clear. One reason may be the reduction in the resting rate of oxygen consumption [23]. Although blood loss does not result in different $\mathrm{StO}_{2}$ or $\mathrm{O}_{2} \mathrm{Hb}$ variables after the vascular occlusion test, it seems to mask the effect of ischemic preconditioning in the blood donor group.

\section{Limitations}

One limitation with our paper is the assumption that withdrawel of $500 \mathrm{ml}$ of blood in a healthy volunteer represents a clinically relevant blood loss. Anyhow 10\% of circulating blood volume can not be neglected.

In addition we did not supply data on base excess and/ or lactate, the two parameters which are conventionally used to estimate tissue oxygenation. This would have helped to indicate whether a $500 \mathrm{ml}$ blood loss was indeed relevant, but was not feasible in the giving setting of volunteer blood donation. Therefore, it is unclear as to whether the device failed to identify tissue ischemia completely, which is unlikely as the values decreased during vascular occlusion, or more likely, that no ischemia developed during blood donation.

\section{Conclusion}

$\mathrm{StO}_{2}$ measured at the thenar eminence seems to be insensitive to blood loss of $500 \mathrm{ml}$ in this setting. Probably blood loss greater than this might lead to detectable changes guiding the treating physician. The exact cut off for detectable changes and the time effect on repeated vascular occlusion tests should be explored further. Until now no such data exist. Finally, our findings suggest that $\mathrm{StO}_{2}$ measured by NIRS is not able to detect acute blood loss of $500 \mathrm{ml}$ and therefore, it might not be useful to apply this device in the acute assessment of a bleeding trauma patient. However, the device could help to identify hemodynamic worsening during the ICU stay but at the moment not enough evidence exists to support this hypothesis.

\section{Competing interests}

The authors declare that they have no competing interests.

\section{Authors' contributions}

VJ, SF and AE conducted the study. All authors contributed to the design of the study, the analysis of the data and the writing of the manuscript. All authors have seen the original study data, reviewed the analysis of the data, and approved the final manuscript. VJ is the author responsible for archiving the study files.

\section{Acknowledgements}

Funding: The present study has been performed without financial support from outside the department of Emergency Medicine.

Previous exhibition: This report has been previously presented, in abstract form, at the ESICM annual congress 2008

\section{Author Details}

1Department of Emergency Medicine, University and University Hospital of Berne (Inselspital), Berne, Switzerland, ${ }^{2}$ Department of Intensive Care Medicine, University and University Hospital of Berne (Inselspital), Berne, Switzerland, ${ }^{3}$ Blood Donation Service SRK, Berne, Switzerland and ${ }^{4}$ Biomedical Optics Research Laboratory, Clinic of Neonatology, University Hospital Zurich, Switzerland

Received: 7 December 2009 Accepted: 13 May 2010

Published: 13 May 2010

References

1. Hamilton-Davies C, Mythen MG, Salmon JB, Jacobson D, Shukla A, Webb AR: Comparison of commonly used clinical indicators of hypovolaemia with gastrointestinal tonometry. Intensive Care Med 1997, 23:276-281.

2. Cohn SM, Varela JE, Giannotti G, Dolich MO, Brown M, Feinstein A McKenney MG, Spalding P: Splanchnic perfusion evaluation during hemorrhage and resuscitation with gastric near-infrared spectroscopy. J Trauma 2001, 50:629-634. discussion 634-625

3. Varela JE, Cohn SM, Giannotti GD, Dolich MO, Ramon H, Wiseberg JA, McKenney M: Near-infrared spectroscopy reflects changes in mesenteric and systemic perfusion during abdominal compartment syndrome. Surgery 2001, 129:363-370.

4. Chaisson NF, Kirschner RA, Deyo DJ, Lopez JA, Prough DS, Kramer GC: Near-infrared spectroscopy-guided closed-loop resuscitation of hemorrhage. J Trauma 2003, 54:S183-192.

5. Cohn SM, Nathens AB, Moore FA, Rhee P, Puyana JC, Moore EE, Beilman $\mathrm{GJ}$ : Tissue oxygen saturation predicts the development of organ dysfunction during traumatic shock resuscitation. J Trauma 2007 62:44-54. discussion 54-45

6. Taylor DE, Simonson SG: Use of near-infrared spectroscopy to monito tissue oxygenation. New Horiz 1996, 4:420-425.

7. Giannotti G, Cohn SM, Brown M, Varela JE, McKenney MG, Wiseberg JA: Utility of near-infrared spectroscopy in the diagnosis of lower extremity compartment syndrome. J Trauma 2000, 48:396-399. discussion 399-401

8. Boushel R, Piantadosi CA: Near-infrared spectroscopy for monitoring muscle oxygenation. Acta Physio/ Scand 2000, 168:615-622.

9. van Beekvelt MC, Borghuis MS, van Engelen BG, Wevers RA, Colier WN Adipose tissue thickness affects in vivo quantitative near-IR spectroscopy in human skeletal muscle. Clin Sci (Lond) 2001, 101:21-28.

10. Rothoerl RD, Faltermeier R, Burger R, Woertgen C, Brawanski A: Dynamic correlation between tissue PO2 and near infrared spectroscopy. Acta Neurochir Supp/ 2002, 81:311-313.

11. Pichler $G$, Urlesberger B, Jirak $P$, Zotter $H$, Muller W: Forearm oxygen consumption and forearm blood flow in healthy children and adolescents measured by near infrared spectroscopy. J Physio/ Sci 2006, 56:191-194

12. Creteur J, Carollo T, Soldati G, Buchele G, De Backer D, Vincent JL: The prognostic value of muscle $\mathrm{StO} 2$ in septic patients. Intensive Care Med 2007, 33:1549-1556. 
13. Crookes BA, Cohn SM, Bloch S, Amortegui J, Manning R, Li P, Proctor MS, Hallal A, Blackbourne LH, Benjamin R, et al:: Can near-infrared spectroscopy identify the severity of shock in trauma patients? Trauma 2005, 58:806-813. discussion 813-806

14. Gomez H, Torres A, Polanco P, Kim HK, Zenker S, Puyana JC, Pinsky MR: Use of non-invasive NIRS during a vascular occlusion test to assess dynamic tissue O(2) saturation response. Intensive Care Med 2008, 34:1600-1607.

15. Toledo P, McCarthy RJ, Hewlett BJ, Fitzgerald PC, Wong CA: The accuracy of blood loss estimation after simulated vaginal delivery. Anesth Analg 2007, 105:1736-1740. table of contents

16. Torella F, Cowley RD, Thorniley MS, McCollum CN: Regional tissue oxygenation during hemorrhage: can near infrared spectroscopy be used to monitor blood loss? Shock 2002, 18:440-444.

17. Soller BR, Yang Y, Soyemi OO, Ryan KL, Rickards CA, Walz JM, Heard SO, Convertino VA: Noninvasively determined muscle oxygen saturation is an early indicator of central hypovolemia in humans. J Appl Physiol 2008, 104:475-481.

18. Smith J, Bricker S, Putnam B: Tissue oxygen saturation predicts the need for early blood transfusion in trauma patients. Am Surg 2008, 74:1006-1011.

19. Myers DE, Anderson LD, Seifert RP, Ortner JP, Cooper CE, Beilman GJ, Mowlem JD: Noninvasive method for measuring local hemoglobin oxygen saturation in tissue using wide gap second derivative nearinfrared spectroscopy. J Biomed Opt 2005, 10:034017.

20. Skarda DE, Mulier KE, Myers DE, Taylor JH, Beilman GJ: Dynamic nearinfrared spectroscopy measurements in patients with severe sepsis. Shock 2007, 27:348-353.

21. Soller BR, Ryan KL, Rickards CA, Cooke WH, Yang Y, Soyemi OO, Crookes BA, Heard SO, Convertino VA: Oxygen saturation determined from deep muscle, not thenar tissue, is an early indicator of central hypovolemia in humans. Crit Care Med 2008, 36:176-182.

22. Gurke L, Mattei A, Chaloupka K, Marx A, Sutter PM, Stierli P, Harder F, Heberer M: Mechanisms of ischemic preconditioning in skeletal muscle. J Surg Res 2000, 94:18-27.

23. Sen A, Martin D, Grocott M, Montgomery H: Changes in thenar eminence tissue oxygen saturation measured using near-infrared spectroscopy suggest ischaemic preconditioning in a repeated arterial occlusion forearm ischaemia model. Critical Care 2008, 12(Suppl 2):P70. (Abstract)

doi: 10.1186/1752-2897-4-5

Cite this article as: Jeger et al, $500 \mathrm{ml}$ of blood loss does not decrease noninvasive tissue oxygen saturation ( $\mathrm{StO} 2$ ) as measured by near infrared spectroscopy - A hypothesis generating pilot study in healthy adult women Journal of Trauma Management \& Outcomes 2010, 4:5

\section{Submit your next manuscript to BioMed Central} and take full advantage of:

- Convenient online submission

- Thorough peer review

- No space constraints or color figure charges

- Immediate publication on acceptance

- Inclusion in PubMed, CAS, Scopus and Google Scholar

- Research which is freely available for redistribution

Submit your manuscript at www.biomedcentral.com/submit
C Biomed Central 